\title{
Effect of FYM, Phosphorus and PSB on Growth, Yield and Quality of Greengram [Vigna radiata (L.) Wilckzek] on Loamy Sand
}

\author{
Karnavat Rekha ${ }^{1 *}$, Pavaya R. P. ${ }^{1}$, Chaudhary Neha ${ }^{1}$ and Sweta Patel ${ }^{2}$
}

${ }^{1}$ Dept. of Agril. Chem. and Soil Science, ${ }^{2}$ Dept. of Agronomy, S. D. Agricultural University, Sardarkrushinagar, Banaskantha, Gujarat (385 506), India

\section{Corresponding Author}

Karnavat Rekha

e-mail: nehakakvadiya@gmail.com

\author{
Article History \\ Article ID: 3C0375b \\ Received in $07^{\text {th }}$ October, 2017 \\ Received in revised form $16^{\text {th }}$ January, 2018 \\ Accepted in final form 29th March, 2018
}

\begin{abstract}
A field experiment was conducted during kharif, 2014 on phosphorus management in greengram to study the effectof two FYM levels viz.,

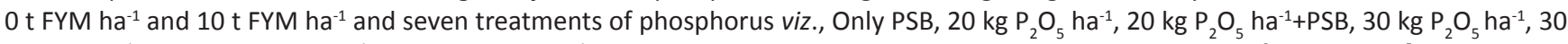
$\mathrm{kg} \mathrm{P}_{2} \mathrm{O}_{5} \mathrm{ha}^{-1}+\mathrm{PSB}, 40 \mathrm{~kg} \mathrm{P}_{2} \mathrm{O}_{5}$ ha $^{-1}$ and $40 \mathrm{~kg} \mathrm{P}_{2} \mathrm{O}_{5}$ ha-1 $^{-1} \mathrm{PSB}$ on growth, yield attributes and yield and economics of greengram [Vigna radiata (L.) Wilckzek]. Application of $10 \mathrm{t} \mathrm{FYM} \mathrm{ha-1} \mathrm{gave} \mathrm{maximum} \mathrm{values} \mathrm{of} \mathrm{all} \mathrm{the} \mathrm{growth} \mathrm{and} \mathrm{yield} \mathrm{attributes} \mathrm{of} \mathrm{greengram.} \mathrm{This} \mathrm{application}$ registered 7.2 and $7.3 \%$ higher seed and stover yield as compared to control respectively. Significantly higher value of growth parameters, yield attributes, yield and quality parameters were recorded with $10 \mathrm{t} \mathrm{FYM} \mathrm{ha-1} \mathrm{application} \mathrm{as} \mathrm{compare} \mathrm{to} \mathrm{no} \mathrm{FYM} \mathrm{application.} \mathrm{Phosphorus}$ application $40 \mathrm{~kg} \mathrm{P}_{2} \mathrm{O}_{5}$ ha $^{-1}+\mathrm{PSB}$ were significantly increased on growth and yield attributes (plant height, branches plant ${ }^{-1}$, root nodules plant $^{-1}$, fresh and dry weight of root nodules, pod length, pods plant ${ }^{-1}, 1000$ grain weight), seed and stover yield compared to PSB only. Application of $40 \mathrm{~kg} \mathrm{P}_{2} \mathrm{O}_{5} \mathrm{ha}^{-1}+\mathrm{PSB}$ resulted significant increase in all these atrributes over PSB only. Absolute control (only PSB) produced significantly poor performance of these attributes than rest treatments.
\end{abstract}

Keywords: Greengram, FYM, Phosphorus, PSB

\section{Introduction}

Green gram is also known as mung, moong, mungo, golden gram, Chickasaw pea and Oregon pea. It contains about $25 \%$ protein, $1.3 \%$ fat, $3.5 \%$ minerals, $4.1 \%$ fiber and $56.7 \%$ carbohydrate. The origin of cultivated green gram is India and central Asia. In India, it occupied an area of 3.44 mha having total production of $18.3 \mathrm{mt}$ of grain with productivity of $1100 \mathrm{~kg} \mathrm{ha}^{-1}$ (Anon., 2013-14). In India, major green gram producing states are Orissa, Madhya Pradesh, Rajasthan, Maharashtra, Gujarat and Bihar. In Gujarat, it is grown on an area of 2.30 lakh ha with the production of 1.21 lakh tones and productivity of $526 \mathrm{~kg} \mathrm{ha}^{-1}$ (Anon., 2010-11). In Banaskantha district,it is grown in area of 182 ha with the production of $86 \mathrm{mt}$ of grain with the productivity of $473 \mathrm{~kg} \mathrm{ha}^{-1}$ (2012-13). Phosphorus plays a keyrole in various physiological processes like root growth and dry matter production, nodulation and nitrogen fixation and also in metabolic activities especially in protein synthesis. It helps in establishing seedling quickly and also hastens maturity as well as improves the quality of crop produce. The most obvious effect of phosphorus is on the root system of plants. It promotes the formation of lateral and fibrous roots, which facilitates to bacteria for nodulation and ultimately increases the nitrogen fixation in leguminous crops. The role of organic manure is well recognized and considered as balance manures which supplies macro and micro nutrients essential toplants Farm yard manure (FYM) is one of the important organic manures, which supplies a suitable mineral balance and improves nutrient availability by enzymes. The PSB like Pseudomonas and Bacillus also enhances the availability of phosphorus to the plant by converting insoluble phosphorus from the soil in the soluble form. The PSB like Pseudomonas striata bacterial inoculation was found as equivalent to supply $50 \mathrm{~kg} \mathrm{P}_{2} \mathrm{O}_{5} \mathrm{ha}^{-1}$ through single super phosphate (Gour et al., 1980). More over use of this bio-fertilizer also reduced the environmental pollution caused by heavy use of chemical fertilizer (Deshmukh and Bhapkar, 1982).

\section{Materials and Methods}

A field experiment was conducted during Kharif, 2014 at Agronomy Instructional Farm, C.P. College of Agriculture, Sardarkrushinagar Dantiwada Agricultural University, Sardarkrushinagar. Fourteen treatment combinations comprising of two FYM levels viz., 0 t FYM ha- ${ }^{-1}\left(F_{0}\right)$ and $10 \mathrm{t}$ FYM ha-1 $\left(F_{1}\right)$ and seven treatments of phosphorus viz., $P_{1}$ (Only 
PSB), $\mathrm{P}_{2}\left(20 \mathrm{~kg} \mathrm{P}_{2} \mathrm{O}_{5} \mathrm{ha}^{-1}\right), \mathrm{P}_{3}\left(20 \mathrm{~kg} \mathrm{P}_{2} \mathrm{O}_{5} \mathrm{ha}^{-1}+\mathrm{PSB}\right), \mathrm{P}_{4}\left(30 \mathrm{~kg} \mathrm{P_{2 } \mathrm { O } _ { 5 }}\right.$ $\left.\mathrm{ha}^{-1}\right), \mathrm{P}_{5}\left(30 \mathrm{~kg} \mathrm{P}_{2} \mathrm{O}_{5} \mathrm{ha}^{-1}+\mathrm{PSB}\right), \mathrm{P}_{6}\left(40 \mathrm{~kg} \mathrm{P}_{2} \mathrm{O}_{5} \mathrm{ha}^{-1}\right)$ and $\mathrm{P}_{7}(40 \mathrm{~kg}$ $\left.\mathrm{P}_{2} \mathrm{O}_{5} \mathrm{ha}^{-1}+\mathrm{PSB}\right)$ were evaluated in factorial randomized block design by replicating three times. The soil of the experimental field was loamy sand in texture, low in organic carbon $(0.17 \%)$, available sulphur (8.50 mg kg-1) and nitrogen (160.7 kg ha-1), medium in available phosphorus (48.9 kg ha-1), iron $(7.60 \mathrm{mg}$ $\left.\mathrm{kg}^{-1}\right)$ and zinc $\left(0.58 \mathrm{mg} \mathrm{kg}^{-1}\right)$ and high in available potash (286 $\mathrm{kg} \mathrm{ha}^{-1}$ ) with $7.6 \mathrm{pH}$.Greengram cultivar GM 4 was sown on first week of July the year behind the plough at row spacing of $45 \mathrm{~cm} @$ of $20 \mathrm{~kg}$ seed ha-1. The plants were spaced at 15 $\mathrm{cm}$ by thinning after 20 days of sowing. PSB was inoculated with seed just before sowing as per treatments requirement. DAP was applied as placement method $3-5 \mathrm{~cm}$ below the seed at time of sowing. At the time of sowing a $20 \mathrm{~kg} \mathrm{~N} \mathrm{ha}^{-1}$ dose was maintained to all treatments for early better growth. The crop was harvested at second week of September. The data on growth and yield attributes were recorded from randomly selected five plants in each plot and seed yield and stover yield recorded from net plot and converted on hectare basis. The protein content in grain was calculated by multiplying nitrogen content of the seed (per cent) with the factor 6.25 as reported by Gupta et al. (1972) and was expressed as percentage. The data were analyzed statistically by adopting the standard procedures described by Panse and Sukhatme (1967).

\section{Results and Discussion}

\subsection{Growth and yield attributes}

Growth (plant height, branches plant ${ }^{-1}$, root nodules plant ${ }^{-1}$, fresh and dry weight of root nodules) and yield attributes (pod length, pods plant ${ }^{-1}$ and 1000 grain weight) (Table 1) were significantly increased FYM @10 t ha-1 application over PSB only. This increase might be owing to batter favorable condition for the microorganisms or helped to make conducive soil for proliferation of microbes in soil that resulted in higher growth of plant and increase weight of root nodules. The marked increase in various yield components with the addition of FYM seems to be not only due to adequate supply of assimilates per nutrients, but also to its pivotal role in informing physico-chemical and biological properties of the soil. Application of phosphorus significantly increased the growth and yield attributes with the increasing levels upto $40 \mathrm{~kg} \mathrm{P}_{2} \mathrm{O}_{5} \mathrm{ha}^{-1}+\mathrm{PSB}$ (Table 1 ). This was largely attributed to better growth of plant which resulted in adequate supply of photosynthates for development of sink under higher level of phosphorus availability. Positive responses in terms of yield attributes to phosphorus application have also been reported by Wagadre et al. (2010); Bhatt, P.K. (2011), Gabhane et al. (2016), Khan et al. (2017) and Das (2017). Rest treatment recorded significantly better growth and yield attributes as compare to control due to poor phosphorus availability in control.

\subsection{Seed and stover yield}

The highest seed (727 kg ha-1) and stover (1399 kg ha-1) was recorded by the application of $40 \mathrm{~kg} \mathrm{P}_{2} \mathrm{O}_{5} \mathrm{ha}^{-1}+\mathrm{PSBas}$ well as FYM @ $10 \mathrm{t} \mathrm{ha}^{-1}$ application over PSB only (Table 2). These results might be clearly suggest that seed yield is an

Table 1: Growth, yield attributes as affected by phosphorus management in greengram

\begin{tabular}{|c|c|c|c|c|c|c|c|c|c|}
\hline Treatments & $\begin{array}{l}\text { Plant } \\
\text { height } \\
(\mathrm{cm})\end{array}$ & $\begin{array}{c}\text { No. of } \\
\text { branches } \\
\text { plant }^{-1}\end{array}$ & $\begin{array}{c}\text { No. of } \\
\text { root } \\
\text { nodules } \\
\text { plant }^{-1}\end{array}$ & $\begin{array}{l}\text { Fresh weight } \\
\text { of root nod- } \\
\text { ules plant }{ }^{-1} \\
\text { (g) }\end{array}$ & $\begin{array}{c}\text { Dry weight } \\
\text { of root } \\
\text { nodules } \\
\text { plant }^{-1} \text { (g) }\end{array}$ & $\begin{array}{c}\text { Pod } \\
\text { length } \\
\text { (cm) }\end{array}$ & $\begin{array}{l}\text { No. of } \\
\text { pods } \\
\text { plant }^{-1}\end{array}$ & $\begin{array}{c}\text { Number } \\
\text { of seeds } \\
\text { pod }^{-1}\end{array}$ & $\begin{array}{c}\text { Test } \\
\text { weight } \\
\text { (g) }\end{array}$ \\
\hline \multicolumn{10}{|l|}{ [A] Levels of FYM (F) } \\
\hline $\mathrm{F}_{0}: 0 \mathrm{tha}^{-1}$ & 43.01 & 6.11 & 79.18 & 1.612 & 0.572 & 7.10 & 19.52 & 9.60 & 40.29 \\
\hline $\mathrm{F}_{1}: 10 \mathrm{t} \mathrm{ha}^{-1}$ & 46.97 & 6.71 & 81.43 & 1.702 & 0.615 & 7.86 & 21.22 & 10.31 & 40.53 \\
\hline SEm \pm & 0.77 & 0.14 & 0.49 & 0.006 & 0.005 & 0.20 & 0.44 & 0.20 & 0.42 \\
\hline $\operatorname{CD}(p=0.05)$ & 2.24 & 0.41 & 1.41 & 0.017 & 0.014 & 0.58 & 1.29 & 0.57 & NS \\
\hline \multicolumn{10}{|c|}{ [B] Phosphorus treatments (P) } \\
\hline$P_{1}: P S B$ & 39.43 & 5.55 & 78.32 & 1.628 & 0.573 & 6.83 & 18.00 & 9.33 & 40.00 \\
\hline $\mathrm{P}_{2}: 20 \mathrm{~kg} \mathrm{P}_{2} \mathrm{O}_{5} \mathrm{ha}^{-1}$ & 42.97 & 5.78 & 78.82 & 1.633 & 0.578 & 6.92 & 19.67 & 9.42 & 40.17 \\
\hline $\mathrm{P}_{3}: 20 \mathrm{~kg} \mathrm{P} \mathrm{O}_{5} \mathrm{ha}^{-1}+\mathrm{PSB}$ & 43.50 & 5.95 & 79.58 & 1.641 & 0.586 & 7.00 & 20.00 & 9.50 & 40.25 \\
\hline $\mathrm{P}_{4}: 30 \mathrm{~kg} \mathrm{P} \mathrm{O}_{5} \mathrm{ha}^{-1}$ & 44.25 & 6.12 & 80.67 & 1.652 & 0.597 & 7.33 & 20.50 & 9.83 & 40.50 \\
\hline$P_{5}: 30 \mathrm{~kg} \mathrm{P}_{2} \mathrm{O}_{5} \mathrm{ha}^{-1}+\mathrm{PSB}$ & 45.32 & 7.12 & 81.17 & 1.677 & 0.602 & 8.01 & 21.02 & 10.33 & 40.58 \\
\hline$P_{6}: 40 \mathrm{~kg} \mathrm{P}_{2} \mathrm{O}_{5} \mathrm{ha}^{-1}$ & 48.93 & 7.17 & 81.22 & 1.679 & 0.604 & 8.08 & 21.67 & 10.58 & 40.67 \\
\hline$P_{7}: 40 \mathrm{~kg} \mathrm{P}_{2} \mathrm{O}_{5} \mathrm{ha}^{-1}+\mathrm{PSB}$ & 50.92 & 7.20 & 82.38 & 1.689 & 0.614 & 8.17 & 21.75 & 10.67 & 40.68 \\
\hline SEm \pm & 1.44 & 0.26 & 0.91 & 0.011 & 0.009 & 0.37 & 0.83 & 0.37 & 0.78 \\
\hline $\operatorname{CD}(p=0.05)$ & 4.20 & 0.77 & 2.64 & 0.031 & 0.026 & 1.08 & 2.41 & NS & NS \\
\hline
\end{tabular}


Table 2: Seed yield, stover yield, Protein content and protein yield as effected by phosphorus management in greengram

\begin{tabular}{ccccc}
\hline Treatments & $\begin{array}{c}\text { Seed } \\
\text { yield } \\
\left(\mathrm{kg} \mathrm{ha}^{-1}\right)\end{array}$ & $\begin{array}{c}\text { Stover } \\
\text { yield }\end{array}$ & $\begin{array}{c}\text { Protein } \\
\left(\mathrm{kg} \mathrm{ha}^{-1}\right)\end{array}$ & $\begin{array}{c}\text { Protein } \\
\text { content }\end{array}$ \\
& $\begin{array}{c}\text { yield } \\
\left(\mathrm{kg} \mathrm{ha}^{-1}\right)\end{array}$ \\
\hline
\end{tabular}

[A] Levels of FYM (F)

\begin{tabular}{lcccc}
\hline $\mathrm{F}_{0}: 0 \mathrm{t} \mathrm{ha}^{-1}$ & 653 & 1253 & 22.26 & 145.67 \\
$\mathrm{~F}_{1}: 10 \mathrm{tha}^{-1}$ & 700 & 1345 & 22.78 & 159.91 \\
SEm \pm & 14 & 28 & 0.18 & 3.92 \\
$\mathrm{CD}(p=0.05)$ & 41 & 82 & NS & 11.40
\end{tabular}

[B] Phosphorus treatments (P)

\begin{tabular}{lcccc}
\hline $\mathrm{P}_{1}: \mathrm{PSB}$ & 621 & 1188 & 22.19 & 137.80 \\
$\mathrm{P}_{2}: 20 \mathrm{~kg} \mathrm{P}_{2} \mathrm{O}_{5}$ & 633 & 1211 & 22.29 & 141.07 \\
$\mathrm{ha}^{-1}$ & & & & \\
$\mathrm{P}_{3}: 20 \mathrm{~kg} \mathrm{P}_{2} \mathrm{O}_{5}$ & 655 & 1256 & 22.45 & 146.99 \\
$\mathrm{ha}^{-1}+\mathrm{PSB}$ & & & & \\
$\mathrm{P}_{4}: 30 \mathrm{~kg} \mathrm{P} \mathrm{O}_{5}$ & 673 & 1293 & 22.50 & 151.52 \\
$\mathrm{ha}^{-1}$ & & & & \\
$\mathrm{P}_{5}: 30 \mathrm{~kg} \mathrm{P}_{2} \mathrm{O}_{5}$ & 708 & 1362 & 22.60 & 160.65 \\
$\mathrm{ha}^{-1}+\mathrm{PSB}$ & & & & \\
$\mathrm{P}_{6}: 40 \mathrm{~kg} \mathrm{P} \mathrm{O}_{5}$ & 721 & 1386 & 22.71 & 164.15 \\
$\mathrm{ha}^{-1}$ & & & & \\
$\mathrm{P}_{7}: 40 \mathrm{~kg} \mathrm{P} \mathrm{O}_{5}$ & 727 & 1399 & 22.92 & 167.35 \\
$\mathrm{ha}$ & & & & \\
$\mathrm{SEm} \pm$ & & 53 & $\mathrm{NS}$ & $\mathrm{NS}$ \\
$\mathrm{CD}(p=0.05)$ & 77 & 154 & 3.16 & 10.08 \\
\hline
\end{tabular}

artifact of several yield components, which are dependent on source (photosynthates/metabolites/nutrients) and sink (yield components particularly number of seeds $\operatorname{pod}^{-1}$ and test weight) and improvement in all these aspects under the influence of organic fertilization resulted in realization of higher productivity in terms of seed yield. Results are in close conformity with the findings of Singh et al. (1998), Shete et al. (2010), Mary et al. (2015) and Meena et al. (2016).

The $40 \mathrm{~kg} \mathrm{P}_{2} \mathrm{O}_{5}$ ha $^{-1}+\mathrm{PSB}\left(\mathrm{P}_{7}\right)$ treatment recorded 17 and 17.76 per cent higher seed and stover yield as compared to only PSB $\left(P_{1}\right)$, respectively. This might be due to significantly increase in $P$ availability and uptake resulted profuse nodulation leading to greater symbiotic $N$ fixation which in turn has positive effect on photosynthesis then on yield ha-1. Response of phosphorus was also reported by Singh et al. (1998), Shete et al. (2010), Gabhane et al. (2016); Patel et al. (2017).

\subsection{Quality parameter}

The protein yield was significantly higherunder $40 \mathrm{~kg} \mathrm{P}_{2} \mathrm{O}_{5}$ ha ${ }^{-1}+$ PSB as well as FYM @ $10 \mathrm{t} \mathrm{ha}^{-1}$ application (Table 2). The protein content is dependent on plant growth and nutritional composition. Increase in protein content in grain may be due to enhanced uptake and translocation of nitrates which provide nitrogen for amino acid synthesis. The results are in close conformity with the findings of Deshmukh et al. (2005), Sutaria et al. (2010); Jat et al. (2012); Dhakal et al. (2016); Venkatarao et al. (2017).

\section{Conclusion}

Based on the experimental results, it is concluded that for obtaining highest greengram production, the crop should befertilized with $40 \mathrm{~kg} \mathrm{P}_{2} \mathrm{O}_{5}$ ha $^{-1}+\mathrm{PSB}$ in loamy sand soil of north Gujarat.

\section{References}

Anonymous, 2010-11. All India Coordinated Research project on MULLARP:-http://www.aicrpmullarp.res.in/crop profile.html.

Bhatt, P.K., 2011. Effect of levels of vermicompost and phosphorus with PSB on growth and yield of summer greengram (Vigna radiate L. Wilczek) under north Gujarat agro climatic condition. M.Sc. (Agri.) thesis submitted to SDAU, Gujarat.

DAS, S.K., 2017. Effect of phosphorus and sulphur on yield attributes, yield, nodulation and nutrient uptake of green gram [Vigna radiate (L.) wilczek]. Legume Research 40(1), 138-143.

Deshmukh, K.K., 2005. effect of integrated use of inorganic, organic and biofertilizers on production, nutrient availability and economic feasibility of soybean grown on soil of Kaymore plateau and Satpura hills. Journal of Soils and Crops 15(1), 21-25.

Deshmukh, R.B., Bhapkar, D.G., 1982. Constraints and opportunity for increase pulse production in Western Maharashtra paper presented at the symposium on increase pulse production in India. Constraints and opportunity held at New Delhi on 9-10 th October, 1982.

Dhakal, Y., Meena, R.S., Kumar, S., 2016. Effect of INM on nodulation, yield, quality and available nutrient status in soil after harvest of greengram. Legume Research 39(4), 590-594.

Gabhane, V.V., Sonune, B.A., Paslawar A.N., Mali, D.V., Harle, S.M., 2016. Response of greengram-safflower cropping sequence to phosphorus management in relation to yield, nutrient uptake and phosphorus use efficiency in vertisols. Legume research 39(1), 61-69.

Gour, A.C., Oswal, K.P., Mathur, R.S., 1980. Save superphosphate by using phosphate solublizing culture and rock phosphate. Kheti 32(10), 23-25.

Gupta, B.R, Pathak, R.K., Bhan, S., Singh, A., 1972. Effect of NPK on yield, nutrient and quality of toria (Brassica compenstris var. toria). Indian Journal of Agronomy 17(2), 88-91.

Jat, R.A., Ahlawat, I.P.S., 2010. Effect of organic manure and sulphur fertilization in pigeonpea (Cajanus cajan)+groundnut (Arachis hypogaea) intercropping 
system. Indian Journal of Agronomy 55(4), 276-281.

Khan, M., Md. Salman, Singh, V.P., Kumar, A., 2017. Studies on Effect of Phosphorous Levels on Growth and Yield of Kharif Mungbean (Vigna radiata L. wilczek). International Journal of Pure \& Applied Bioscience 5(4), 800-808.

Mary, J.A.L., Nithiya, T., 2015. Effect of organic and inorganic fertilizer on growth, phenolic compounds and antioxidant activity of Solanum nigrum L. World Journal of Pharmacy and Pharmaceutical Sciences 4(5), 808-822.

Meena, S., Swaroop, N., Dawson, J., 2016. Effect of integrated nutrient management on growth and yield of green gram (Vigna radiata L.). Agricultural Science Digest 36(1) 2016, 63-65

Panse, V.G., Sukhatme, P.V., 1967. Statistical methods for agricultural workers. Indian Council of Agricultural Research, New Delhi.

Patel, H.B., Shah, K.A., Barvaliya, M.M., Patel, S.A., 2017. Response of greengram (Vigna radiata L.) to different level of phosphorus and organic liquid fertilizer. International Journal of Current Microbiology and Applied Sciences 6(10)-3443-3451.

Patel, R.D., Patel, D.D., Chaudhari, M.P., Surve, Vaishali., Patel, K.G., Tandel, B.B., 2013. Response of different cultivars of greengram to integrated nutrient management under South Gujarat condition. AGRES-An International e-Journal 2(2), 132-142.
Shete, P.G., Thanki, J.D., Adhav, S.L., Kushare, Y.M., 2010. Response of rabi greengram (Vigna radiata L.) to land configuration and inorganic fertilizer with and without FYM. Crop Research-An International Journal 39(1/2/3), 43-46.

Singh, M., Tripathi, A.K., Kundu, S., Ramana, S., Takkar, P.N., 1998. Effect of seed inoculation and FYM on biological $N$ fixation in soybean and nitrogen balance under soybeanwheat system on vertisoil. Journal of the Indian Society of Soil Science 46(4), 604-609.

Sutaria, G.S., Akbari, K.N., Vora, V.D., Hirpara, D.S., Padmani, D.R., 2010. Influence of phosphorus and FYM on content and uptake of nutrients by groundnut and soil fertility of Verticustochrepts under rainfed conditions. Asian Journal of Soil Science 5(1), 197-199.

Venkatarao, C.V., Naga, S.R., Yadav, B.L., Koli, Kumar, D., Rao, I.J., 2017. Effect of Phosphorus and Biofertilizers on Growth and Yield of Mungbean [Vigna radiata (L.) Wilczek]. International Journal of Current Microbiology and Applied Sciences 6(7)- 3992-3997.

Wagadre, N., Patel, M.V., Patel, H.K., 2010. Response of summer greengram (vigna radiata $\mathrm{L}$.) to vermicompost and phosphorus with and without PSB inoculation. State level seminar on organic farming, Nvasari, Gujarat. 111-114. 